\title{
Job destruction and closures in deindustrialising Britain; the uses and decline of workplace occupations in the 1980s
}

DOI:

10.3828/lhr.2021.5

\section{Document Version}

Accepted author manuscript

Link to publication record in Manchester Research Explorer

Citation for published version (APA):

Mustchin, S. (2021). Job destruction and closures in deindustrialising Britain; the uses and decline of workplace occupations in the 1980s. Labour History Review, 86(1), 91-115. https://doi.org/10.3828//hr.2021.5

\section{Published in:}

Labour History Review

\section{Citing this paper}

Please note that where the full-text provided on Manchester Research Explorer is the Author Accepted Manuscript or Proof version this may differ from the final Published version. If citing, it is advised that you check and use the publisher's definitive version.

\section{General rights}

Copyright and moral rights for the publications made accessible in the Research Explorer are retained by the authors and/or other copyright owners and it is a condition of accessing publications that users recognise and abide by the legal requirements associated with these rights.

\section{Takedown policy}

If you believe that this document breaches copyright please refer to the University of Manchester's Takedown Procedures [http://man.ac.uk/04Y6Bo] or contact uml.scholarlycommunications@manchester.ac.uk providing relevant details, so we can investigate your claim.

\section{OPEN ACCESS}




\title{
Job destruction and closures in deindustrialising Britain; the uses and decline of workplace occupations in the 1980s
}

\author{
Stephen Mustchin \\ University of Manchester \\ Author Accepted Manuscript \\ Published in Labour History Review, 86:1, 91-115
}

\begin{abstract}
This article considers the uses and decline of workplace occupations in the 1980s. Developing the contribution by Alan Tuckman on the rise of occupations in the 1970s, attention is given to the structural factors that can explain the reasons why workers' uses of the tactics have declined since the period. Focusing on the wider context and two contrasting cases (the 1980 Gardner and 1984 Cammell Laird occupations), this article advances six key reasons why this decline has taken place. First, the decline of manufacturing and rising unemployment in the 1980s; second, an overall decline in strikes more generally in terms of their incidence and duration; third, anti-union legislation and policing; fourth, the lack of a positive demonstration effect with regard to 'successful' examples of occupations in the 1980s; fifth, the decline of debates around alternative forms of ownership including nationalization and the incipient workers control/ cooperatives movement, and sixth, the decline of the far left and the networks that had sustained occupations to some extent in the 1970s and 1980s.
\end{abstract}

\section{Introduction}

Workplace occupations and sit-in strikes are an enduring phenomenon occurring in a wide range of national and industrial contexts. The use of such tactics has risen and fallen over time and featured in diverse and unconnected parts of the world. Notable examples of the use of occupations include the factory soviets in the 1905 and 1917 Russian revolutions, factory occupations involving over half a million workers in Italy in 1920, in the auto industry in France and the US in the mid-1930s, 1968 in France and, in the case of Britain, a wave of workplace occupations in the 1970s following the famous occupation and work-in at Upper Clyde Shipbuilders (UCS). ${ }^{1}$ As outlined in the previous contributions, the tactic of occupation was often used in opposition to closures and mass job losses, and was used in certain circumstances as it gave workers greater capacity to prevent strike breakers and management from entering a workplace during a dispute and greater control over the movement of assets and materials than more traditional picketing. ${ }^{2}$ Building on the preceding case study articles, this paper explores the reasons why workplace occupations declined and almost disappeared in Britain in the 1980s, with reference to the wider political, economic, legal and social context, as well as drawing on case studies of particular occupations to highlight how these wider macro-level factors influenced workplace occupations at the level of individual disputes. ${ }^{3}$

\footnotetext{
${ }^{1}$ Dave Sherry, Occupy! A short history of workers' occupations (Bookmarks: 2010).

${ }^{2}$ Gregor Gall, 'Occupations, not Occupy!', Capital and Class, 42:3 (2018), 393-401, 9.

${ }^{3}$ A range of significant workplace occupations in the 1980s are analysed and referenced within this article, predominantly drawing on secondary sources, but the case study material draws particularly on two published articles by the author on the 1980 and 1984 occupations at Gardner and Cammell Laird respectively, which draw more from primary source material - see Stephen Mustchin, 'Conflict, mobilization and deindustrialization; the 1980 Gardner strike and its wider implications', Historical Studies in Industrial Relations, 37 (2016)141-67; Stephen Mustchin, 'From workplace occupation to mass imprisonment: The 1984 strike and occupation at Cammell Laird Shipbuilders', Historical Studies in Industrial Relations, 31/32 (2011), 31-61.
} 
Much academic interest in factory occupations relates to the way that they challenge property rights and the organisation of capitalism and have sometimes presaged movements towards workers control and self-managed enterprises. Worker takeovers of organisations under 'collective administration' have been described as a 'natural tendency of rank-and-file workers', even for those without knowledge or connection to previous or historical experiences. ${ }^{4}$ Prominent examples of such takeovers in the British context in the 1970s include the UCS work-in ${ }^{5}$ and the so-called 'Benn cooperatives', Meriden, Lucas and Imperial, firms that were occupied by their workforces due to the threat of closure and which gained support from then-Industry secretary Tony Benn to continue under worker self-management. ${ }^{6}$ Such developments involving workers control and the UCS experience were highlighted by Hyman as "qualitative...advances in struggle." These developments can be framed within a wider upsurge of interest in worker participation and involvement in the mid-1970s, deriving from parts of the union movement as well as (to an extent) the Labour Party, culminating in the Royal Commission on Industrial Democracy (the Bullock report). ${ }^{8}$ Proposals from Labour figures including Anthony Crosland to extend collective bargaining 'over the whole range of managerial functions, including the formulation and application of the company's corporate plan' and challenging sole managerial prerogative ${ }^{9}$ became increasingly prominent, but faced increasing levels of opposition from the right. John Hoskyns, later an advisor to Thatcher and a key figure in the Stepping Stones program that devised the anti-union laws later passed in the 1980s, dismissed such ideas as 'completely impractical, this sort of thing encouraged union leaders and shop stewards to think that they were above the law, and should be running businesses, and perhaps the country itself.' 10

A problem with some analyses of these issues is that occupations and sit-ins are to an extent conflated with work-ins and workers' control.. In the UK context, it is important to realise that occupation as a tactic was only rarely related to work-ins, worker cooperatives and similar. The UCS example was exceptional, and the vast majority of occupations constituted 'a revolutionary tactic [...] for reformist demands'. ${ }^{11}$ A wave of occupations seeking to resist closure, collective redundancies and to improve redundancy terms took place in the 1980s, including Gardner $(1980)^{12}$, Laurence Scott $(1981)^{13}$, Plessey $(1982)^{14}$, Lee Jeans $(1982)^{15}$ and Cammell Laird (1984). ${ }^{16}$ Occupations became less frequent from the mid-1980s onwards, in line with the wider decline of industrial action following the miners' strike and the introduction of anti-union legislation. More isolated examples followed, including the Caterpillar

\footnotetext{
${ }^{4}$ Immanuel Ness and Dario Azzelini, Ours to Master and to Own: Workers' control from the commune to the present (Chicago, Haymarket: 2011), 1.

${ }^{5}$ John Foster and Charles Woolfson, The Politics of the UCS Work-In (Lawrence and Wishart: 1986).

${ }^{6}$ Alan Tuckman, 'Workers Control and the Politics of Factory Occupation: Britain, 1970s.' In Ness and Azzelini, Ours to Master and to Own, 284-301.

${ }^{7}$ Richard Hyman, 'Afterword: What Went Wrong?', in John Mcllroy, Nina Fishman and Alan Campbell, The High Tide of British Trade Unionism: Trade Unions and Industrial Politics, 1964-79 (Monmouth, Merlin Press: 2007), 353-64, 358.

8 Jim Phillips, 'UK Business Power and Opposition to the Bullock Committee's 1977 Proposals on Worker Directors', Historical Studies in Industrial Relations, 31/32 (2011), 1-30.

9 Anthony Crosland, Socialism Now, (Jonathan Cape: 1974), cited in John Hoskyns, Just In Time - Inside the Thatcher Revolution. (Aurum: 2000), 62.

${ }^{10}$ Hoskyns, Just In Time, 62.

${ }^{11}$ Socialist Worker, 22 November 1980

${ }^{12}$ Mustchin, 'Conflict, mobilization, and deindustrialization'

${ }^{13}$ Colin Love, Conflicts over Closure: The Laurence Scott Affair (Avebury, Aldershot: 1988).

${ }^{14}$ Patricia Findlay, 'Resistance, Restructuring and Gender: The Plessey Occupation', in T. Dickson and D. Judge (eds), The Politics of Industrial Closure (Macmillan, Basingstoke: 1987)

${ }^{15}$ Andy Clark, " "And the next thing the chairs barricaded the door": the Lee Jeans factory occupation, trade unionism and gender in Scotland in the 1980s', Scottish Labour History, 48, (2013) 116-134; Nick Lorentzen, "'You can't fight for jobs and just sit there": The Lee Jeans Sit-in', in H. Levie, D. Gregory and N. Lorentzen (eds), Fighting Closures: De-Industrialization and the Trade Unions 1979-1983 (Spokesman, Nottingham: 1984) 43-62.

${ }^{16}$ Mustchin, 'From workplace occupation to mass imprisonment'
} 
occupation in $1987^{17}$, sit-ins in the offshore oil industry in $1990^{18}$, Glacier Metal engineering workers in Glasgow in 1996, and a series of examples in the UK and Ireland following the 2008 financial crisis. ${ }^{19}$ However, occupations have dissipated markedly overall as a tactic within strikes, and this article advances six key reasons why this decline has taken place. First, the decline of manufacturing and rising unemployment in the 1980s; second, an overall decline in strikes more generally in terms of their incidence and duration; third, anti-union legislation and policing; fourth, the lack of a positive demonstration effect with regard to 'successful' examples of occupations in the 1980s; fifth, the marginalization of debates around alternative forms of ownership including nationalization and the incipient workers control/ cooperatives movement, and sixth, the decline of the far left and the networks that had sustained occupations to some extent in the 1970s and 1980s. The section that follows outlines the development and growing use of the occupations in the 1970s and their decline in the 1980s. This is followed by some more theoretical considerations regarding workplace occupations to frame subsequent analysis of these six explanations for the decline in use of occupations within strikes. The discussion and analysis that concludes the paper explores the significance of and interrelationships between these factors and their wider significance in terms of the use of occupations during strikes but also within wider social movements outside the labour movement.

\section{The decline of workplace occupations in Britain}

An estimated 268 workplace occupations took place in Britain between 1971 and 1981 (with 116 of these concerning redundancies). ${ }^{20}$ Occupations had risen in prevalence during the strike wave of the 1970s, opposing restructuring and job destruction, saving jobs in some instances, acting as a precursor to new forms of ownership and control in others, but predominantly being used for offensive rather than defensive purposes, i.e. as a strike tactic to advance claims regarding pay and conditions of employment rather than in more defensively or to attempt to resist closure and redundancy. The use of occupations was to an extent legitimised within TUC policy in the mid-1970s - while occupation was generally unlawful, the TUC acknowledged it as a legitimate tactic in certain circumstances, including work-ins, occupations in protest over closure and job losses, or to advance collective bargaining or wider strategic objectives. ${ }^{21}$ Strategic use of occupations was rare given the general lack of support for the tactic from union bureaucracies, and while high profile examples of work-ins arose, as at UCS, they were also a rarity. Occupations in the 1980s were increasingly defensive and organised in opposition to management decisions over job losses and restructuring. Around 100 occupations took place in Britain between 1979 and 1985, chiefly in manufacturing but also the printing and shipping industries, but after 1985 and the subsequent fall in industrial action following the defeat of the miners in the 1984/5 strike, the use of the tactic became very rare indeed. ${ }^{22}$ The wider decline of industrial action more generally in the 1980s, in conjunction with a more hostile legal environment, the disciplining effect of mass unemployment, hardened government attitudes

\footnotetext{
${ }^{17}$ Charles Woolfson and John Foster, Track Record: The Story of the Caterpillar Occupation (Verso: 1988); Ewan Gibbs and Jim Phillips 'Who owns a factory?: Caterpillar tractors in Uddingston, 1956-1987', Historical Studies in Industrial Relations, 39 (2018), 111-137.

${ }^{18}$ Charles Woolfson, John Foster and Matthias Beck, Paying for the Piper: capital and labour in Britain's offshore oil industry. (Mansell: 1996), 182.

${ }^{19} \mathrm{G}$. Gall, 'Resisting recession and redundancy'

${ }^{20}$ See 'Workplace Occupations in the United Kingdom: 1971 to 2019', this issue.

${ }^{21}$ Michael Gold, 'Worker Mobilization in the 1970s: Revisiting Work-ins, Co-operatives and Alternative Corporate Plans', Historical Studies in Industrial Relations, 18 (2004), 65-106, 75.

${ }^{22}$ Gregor Gall, 'Resisting Recession and Redundancy - Contemporary Worker Occupations in Britain', Working USA, 13:1 (2010), 107-32; P. Heaton, 'Challenging Redundancy in Shipping', in H. Levie, D. Gregory and N. Lorentzen (eds), Fighting Closures: De-Industrialization and the Trade Unions 1979-1983 (Spokesman, Nottingham: 1984), 77-84.
} 
towards supporting struggling industries, and shifts within the internal politics of the union movement all contributed towards the declining use of the occupation tactic within strikes.

While occupations remained unlawful in the 1970s, prosecutions remained very rare. A 1976 Institute of Personnel Management publication advised that occupations were an industrial relations problem to be addressed within more independent union-management relations rather than with recourse to state agencies and the law, which would damage future 'industrial relationships'. ${ }^{23}$ Considerable levels of reaction were evident from the right in this period. The right-wing, Conservative Party-linked business pressure group Aims of Industry were highly critical of how UCS had propagated 'the view that it is somehow right and natural for employees to occupy their factory and make use of their employers' property if they are faced with redundancy. ${ }^{24}$ In 1974, predicting strengthened labour law and employment guarantees under a future Labour government, Aims of Industry predicted an apocalyptic scenario where in five years' time the country would suffer 'violent aggro', that local elections would be won by 'the anarchist groups running the sit-ins', that extreme right-wing groups would take over some local authorities, acting as an unofficial police force to clear occupied factories of anarchists, that the 'trade union movement will then use its monopoly power to create no-go areas in the country', and that extreme right and left 'will then probably start throwing some bombs at each other'; subsequently '[p]erhaps the army will be called in to be a power in the streets in Mainland Britain. ${ }^{25}$ Occupations had taken place in GKN, Hawker Siddeley, McAlpine, and Taylor Woodrow workplaces - these firms were significant donors to right-wing pressure groups in the period and senior executives held board level roles with organizations such as the Economic League, Aims of Industry and the National Association for Freedom, who were increasingly vocal on the perceived risks of union militancy and in some cases occupations more specifically. ${ }^{26}$ Occupations were framed within a wider narrative that bemoaned militant trade unionism, the prospect of strengthened employment regulation and codetermination rights from both Labour governments and Europe, and wider anxieties regarding the left, social order, 'domestic subversion' and the decline of manufacturing. The occupation and work-in at UCS, with the subsequent 'u-turn' by the Heath government in terms of providing state aid for struggling industries in contrast with the free market ideology initially espoused (the 'Selsdon Programme'), took on a great significance on the right of the Conservative Party and informed the move towards the increasingly neoliberal positions of the Thatcher-led party after $1975 .^{27}$ This political context, which informed future Conservative governments taking a far more punitive line with striking workers and challenges to property rights, along with the recession, job destruction and mass unemployment that followed in the 1980 s, were central to the countermovement against strikes in general and occupations in particular.

An estimated 100 occupations took place between 1979 and $1985^{28}$, including notable examples at Gardner (1980), Lee Jeans (1981), Lawrence Scott (1981/2), Plessey in Bathgate (1982), BPCC (1983), Massey Ferguson (1983), Timex (1983) and Thomas Scott's (1984). ${ }^{29}$ Further occupations in manufacturing included Meccano in Liverpool in $1979,{ }^{30}$ and in the early 1980s Smiths Industries in Cricklewood, Essex International in Ayrshire, Chloride in

\footnotetext{
${ }^{23}$ Institute of Personnel Management (IPM) Sit-Ins and Work-Ins (London, Institute for Personnel Management: 1976)

${ }^{24}$ Frank Broadway, 'Power on the shopfloor: co-operation, control or chaos?' (Aims of Industry:1972), 13.

${ }^{25}$ Aims of Industry, 'Halfway to $1984-1979$ ' (1974), 15.

${ }^{26}$ Albert Mills, 'Worker occupations, 1971-1975: a sociohistorical analysis of the development and spread of sit-ins, work-ins and worker co-operative in Britain' (Doctoral thesis, Durham University: 1982), 366-377; Mike Hughes, Spies at Work (selfpublished: 2012)

${ }^{27}$ Andrew Denham and Mark Garnett, Keith Joseph (Acumen: Chesham, 2001),228; Norman Tebbit, Upwardly Mobile (Weidenfield and Nicolson: 1988), 112.

${ }^{28}$ Gall, 'Resisting Recession and Redundancy', 111.

${ }^{29}$ Sherry, Occupy!, 131; Mustchin, 'From occupation to mass imprisonment', 34/5.

${ }^{30}$ Kenneth Brown, 'Unions and Management in Engineering: A Case Study, 1964-79', Business History 47:1 (2006), 86-101
} 
Dagenham, Plessey in Kirkby, Drylanders in St Helens and GEC in Coventry. ${ }^{31}$ Some notable examples followed this period, including at Caterpillar in $1987^{32}$, unofficial sit-ins on North Sea oil platforms in $1990^{33}$ and the 1996 occupation at Glacier Metal in Glasgow. ${ }^{34}$ However, the broader trend was, a near-disappearance of the use of occupation as a strike tactic coterminous with the wider decline in strikes following the defeat of the miners in 1984/5. Some notable occupations took place between 2007 and 2010 in the midst of the financial crisis, including seven in the UK (most notably the wind turbine manufacturer Vestas and car component manufacturer Visteon), several small occupations between 2000 and 2007, and several in the Republic of Ireland (Thomas Cook, Waterford Crystal and 4-Homes Superstores). ${ }^{35}$ Nineteen occupations and sit-ins took place between 2000 and 2010, and a further twelve between 2010 and $2017^{36}$ in diverse contexts including Independent Workers of Great Britain (IWGB)-organised temporary occupations or sit-ins of corporate headquarters as part of leverage campaigns, ${ }^{37}$ construction engineering workers at a power plant in Nottinghamshire in 2010, refuse workers in Brighton in 2013, and the largest and longest taking place at Burntisland Fabrications (BiFab) in Scotland in 2017. ${ }^{38}$ A further workplace occupation involving over 100 workers took place in 2019 at the Belfast Harland and Wolff shipyard in opposition to proposed closure, with a return to work agreed once administrators accepted a new bid for the site. ${ }^{39}$ The tactic is, then an enduring one, although its use has fallen markedly from the 1971-1985 period when they were at their peak.

\section{The politics and academic analysis of workplace occupations}

Numerous accounts of individual occupations have been published ${ }^{40}$, and within the strike literature there exists some analysis of strikes over closure and redundancy. ${ }^{41}$ Strikes over job losses have been highlighted as more likely when union organization and institutional strength is threatened, however this is not borne out in the British context of workplace occupations as these were typically driven from below with union leaderships usually reluctant or unwilling to support them. ${ }^{42}$ Much of the academic interest in workers occupations is underpinned by the way in which they challenge notions of property, ownership, who controls the workplace, and how such occupations have occasionally led to work-ins and new organizational forms with greater worker involvement. Occupations are significant for the 'direct challenge workers' control poses to corporate hegemony. ${ }^{43}$ However, in the British context occupation was most

\footnotetext{
${ }^{31}$ Sherry, Occupy!, 127.

${ }^{32}$ Foster and Woolfson, The Politics of the UCS Work-in; Gibb and Phillips, 'Who owns a factory?'

${ }^{33}$ Woolfson et al, Paying for the Piper

${ }^{34}$ Gall, 'Resisting Recession and Redundancy'

${ }^{35}$ Gall, 'Resisting Recession and Redundancy'; Niall Cullinane and Tony Dundon, 'Redundancy and workplace occupation: the case of the Republic of Ireland', Employee Relations, 33:6 (2011), 624-641.

${ }^{36}$ Gall, 2018, 'Occupations, not Occupy!'

${ }^{37}$ Gabriella Alberti, "Mobilizing and bargaining at the edge of informality: The "3 cosas campaign" by outsourced migrant workers at the University of London', WorkingUSA, 19:1 (2016), 81-103, 92.

${ }^{38}$ Gall, 2018, 'Occupations, not Occupy!'

${ }^{39}$ GMB, 'Landmark victory for Harland and Wolff workers as yard saved', 1 October 2019, accessed from https://www.gmb.org.uk/news/landmark-victory-harland-and-wolff-workers-yard-saved , 7.1. 2020.
}

\footnotetext{
40 Mustchin 'From Occupation to Mass Imprisonment'; 'Conflict, Mobilization, and Deindustrialization'; Foster and Woolfson, The Politics of the UCS Work-in; Love, Conflicts over Closure; Clark, 'And the next thing'; Gibb and Phillips, 'Who owns a factory?'; Woolfson and Foster, Track Record

${ }^{41}$ T. Dickson and D. Judge (eds), The Politics of Industrial Closure (Macmillan, Basingstoke: 1987), Levie et al, Fighting Closures

${ }^{42}$ Miriam Golden, Heroic Defeats: The Politics of Job Loss (Cambridge University Press: 1997)

${ }^{43}$ Immanuel Ness, 'Workers' Direct Action and Factory Control in the United States', in Ness and Azzelini (eds.) Ours to Master and to Own, 302-321, 319.
} 
commonly used over relatively mainstream bargaining issues relating to redundancy, preserving jobs, negotiating improved severance terms, and in some cases pay, in the form of the 'collective bargaining sit-ins' identified by the TUC in the 1970s. ${ }^{44}$ Work-ins were relatively uncommon, which is unsurprising given the leverage gained from occupying would typically aim to disrupt production or prevent the removal of assets from a workplace threatened with closure as opposed to maintaining output.

The politics of occupation are also significant within the development and decline of its use within industrial conflict. Structural power, deriving from the position of workers within complex production processes and their capacity to disrupt them, and associational power, or the collective networks serving to sustain such mobilizations, are important variables when analysing the dynamics of workplace occupations. In comparing the 1930s auto workers sitdown strikes in the US and those in Paris in 1968, Silver highlights the US workers comparative lack of associational power within wider society compared to those occupying in France, highlighting their position in the production process as the basis of the structural power that led to the gains that followed in the US. ${ }^{45}$ The relationship between occupations and the production process, and their particular prevalence in engineering, is discussed further below. In terms of associational power, support from political networks has been significant in determining whether occupation is used in a strategic way by labour movements. In Spain and France, occupations gained a degree of support from peak-level union federations with political affiliations ${ }^{46}$ that were absent in the UK case where the industrial - political divide between the TUC and the Labour Party is more pronounced. In the UK, left networks were significant in terms of occupations. The majority of occupations in the 1970s were in AUEW organised workplaces, and it has been argued that strong workplace shop steward organisation, relatively high levels of Communist Party (CP) presence and a broadly supportive left union leadership in the 1970s when Hugh Scanlon was general secretary were critical factors in terms of why occupations became prevalent. ${ }^{47}$ Prominent $\mathrm{CP}$ members and support networks were crucial within the UCS work-in, and in the 1980 Gardner occupation networks encompassing labour movement activists with CP and Socialist Workers Party (SWP) affiliations were important in sustaining the strike, publicizing it and leveraging the threat of 'blacking' which was important in settling the strike. Both the CP and SWP were broadly supportive of occupations where they occurred but in more strategic terms viewed them as a distraction from building party organization. ${ }^{48}$ Risks were also associated with workers control, with Arthur Scargill taking the view that 'workers' control means in effect the castration of the trade union movement' and 'total collaboration as far as the working class is involved. ${ }^{49}$ In Batstone et al's studies of workplace trade unionism and strikes, sit-down techniques had been used informally and calls were made from some more militant members to turn their strike into an occupation, but the caution of the steward leadership was evident, arguing that occupations rarely worked and that securing the consent of the wider membership for such action would be very difficult, especially within a pay dispute compared to one centred on job loss and closure. ${ }^{50}$

In assessing how and why the use of the occupation tactic declined in the 1980s, this article draws on research by the author focusing on two relatively high profile occupations in the period; the 1980 strike and occupation at L. Gardner and Sons, a diesel engine factory in Eccles, Greater Manchester, and the 1984 occupation at the Cammell Laird shipyard in

\footnotetext{
${ }^{44}$ Gold, 'Worker Mobilization'

${ }^{45}$ Beverly Silver, Forces of Labor: Workers Movements and Globalization since 1870. (Cambridge University Press: 2003$), 50$.

${ }^{46}$ Miguel Martinez Lucio, 'From action to communication?: Explaining the changing context of worker occupations as direct forms of action with reference to the case of contemporary Spain', Employee Relations, 33, 6 (2011), 654-669.

${ }^{47}$ Mills, 'Worker occupations, 1971-1975', 383.

${ }^{48}$ Gold, 'Worker Mobilization in the 1970s', 90.

${ }^{49}$ Ibid., 101.

${ }^{50}$ Eric Batstone, Ian Boraston and Stephen Frenkel, The Social Organization of Strikes (Blackwell, Oxford: 1978), 178.
} 
Birkenhead, Merseyside. These two examples are useful as vignettes of how the use of occupations evolved during the Thatcher period, with the Gardner occupation deemed somewhat successful at the time, although the Cammell Laird occupation constituted a defeat caused by divides among the workforce and a forceful response from the state, and was one of the last major occupations in the period before a significant decline in their usage. The 1980 Gardner occupation took place within a firm that had been family owned since 1868 but was taken over by the multinational engineering conglomerate Hawker Siddeley in $1975 .{ }^{51}$ A series of strikes took place from the late 1960s onwards, including in 1968 (over the dismissal of a foundry worker accused of sabotage), in 1972 over pay (separately from the wider wave of engineering occupations in Greater Manchester in 1972 in which the Gardner workforce did not participate $)^{52}$ and, significantly, in 1973 which involved a partial occupation of the plant. The 7 week strike and occupation in 1980 was remarkable in that the workforce were relatively united, widespread solidarity and delegation work took place to build support and collect funds to support the dispute, and was broadly seen at the time as a victory in that large numbers of compulsory redundancies were avoided. Between 200 and 300 workers were in occupation at the plant at any one time during this dispute with management locked out and the plant completely shut down. The aftermath of the strike saw senior stewards and the organizers of the occupation leaving and in some cases victimized, with job losses continuing through the decade and the plant ultimately ceasing engine production in 1994 and closing in 2000. Nonetheless, the occupation was deemed to be a relatively successful example of collective action in opposition to redundancies during the recession of the 1980s, rising unemployment and the initial impact of the Thatcher government's economic policies.

The strike at Cammell Laird shipbuilders took place between June and October 1984. The occupation tactic had been used in the yard previously - in 1975, laid off construction workers staged a three month occupation that was ultimately broken up by the police with eleven workers ending up in court. ${ }^{53}$ The yard had been nationalized in 1977, but shipbuilding was re-privatised following the 1983 British Shipbuilders Act. ${ }^{54}$ Shipbuilding had long been characterized by sectionalism and rigid trade demarcations ${ }^{55}$, and this divided, multi-union context underpinned the difficulties of organizing the kind of unified action seen in the earlier Gardner case. An initial strike was triggered by the announcement of mass redundancies and evolved into a partial occupation of the yard. A group of workers occupied an unfinished gas accommodation rig and a Royal Navy Type 42 destroyer, facing opposition from an organised back-to-work movement with opaque sources of support and funding. Eventually, the final group of occupying workers were effectively under police siege on the gas rig and evicted by (it is assumed) military special forces. 37 workers were imprisoned for one month for contempt of court over a failure to observe a previous court judgement ordering them to leave the yard under trespass law. While support and solidarity for the strikers was evident, the narrowing of immunities set out in the 1982 Employment Act and an unusually forceful response to occupation from the employer in conjunction with the state led to the breaking of the strike. While occupations at Caterpillar in 1987 and a number of smaller actions took place in the aftermath of this dispute, the arrests of the Cammell Laird occupiers represented a major defeat for workers using the occupation tactic. This, in conjunction with the defeat of the miners, contributed towards a wider 'demonstration effect' which led to a broader decline in strikes more generally but particularly strikes against job destruction and closures.

\footnotetext{
${ }^{51}$ Mustchin, 'Conflict, Mobilization, and Deindustrialization'

52 Ralph Darlington and Dave Lyddon, Glorious Summer: Class Struggle in Britain, 1972 (Bookmarks: 2001), 121-22.

${ }^{53}$ Guardian 8 July 1975

${ }^{54}$ Mustchin, 'From Occupation to Mass Imprisonment', 39.

${ }^{55}$ R. K. Brown, P. Brannen, J. M. Cousins and M. L. Samphier, 'The Contours of Solidarity: Social Stratification and Industrial Relations in Shipbuilding', British Journal of Industrial Relations, 10:1 (1972), 12-41.
} 
This article analyses and explains why workplace occupations declined so markedly in the 1980s, drawing on the cases of strikes and occupations at Gardner in 1980 and Cammell Laird in 1984, with reference to others in the period. Gall identified six critical influences explaining the willingness of workers to undertake occupations in certain circumstances: the collectivised nature of redundancy; the immediate and unforeseen nature of redundancy; loss of deferred wages in the form of pensions; pre-existing collectivisation; and positive demonstration effects or influences from other occupations deemed to be successful. ${ }^{56}$ In the analysis that follows, six reasons that were critical to the decline in use of workplace occupations are analysed: the decline of manufacturing and rising unemployment; an overall decline in strikes more generally in terms of their incidence and duration; anti-union legislation and policing; lack of a demonstration effect or the presence of a negative one; the decline of debates over alternative forms of ownership including nationalization and the incipient workers control/ cooperatives movement; and the decline of far- left influence within the trade unions. The impact of these six factors on the phenomenon of workplace occupations is analysed using these two case studies of occupations from the 1980s, along with wider examples, in order to highlight the micro-level dynamics of such broader changes and their more local manifestations.

\section{Explaining the decline of workplace occupations in 1980s Britain}

\section{Job destruction, closures in manufacturing and rising unemployment in the 1980s.}

The recession of the early 1980s accelerated the decline of manufacturing in Britain, with widespread closures and job losses exacerbated by 'monetarist' policies that raised interest and exchange rates in an attempt to control inflation through the money supply, reduced state subsidy for nationalised industries, tolerated rising unemployment and marginalised trade unions. In Britain occupations were most common in manufacturing and engineering workplaces. ${ }^{57}$ In practical terms, occupation as a tactic often constituted preventing a product from leaving the factory premises in order to gain leverage over employers. ${ }^{58}$ A decline in manufacturing employment and the contraction of the engineering industry meant a reduction in the spaces within which occupations could potentially take place. Maintaining orders and sales was of growing importance to the survival of increasingly exposed domestic firms, and this message was often reinforced in management-workforce communications under the auspices of ostensibly participative human resource management practices influenced by unitarist notions of common interests between employers and workers. ${ }^{59}$ Strike action that could damage this was strongly warned against, discouraged and evidently risky, both from the employer side but also from the increasingly cautious leaderships of unions. ${ }^{60}$ Manufacturing job losses in the period and increasing levels of unemployment evidently reduced the bargaining power and workplace strength of unions. Fear of losing jobs with no alternative employment played a major role in reducing strike levels more generally, ${ }^{61}$ and by extension militated against the likelihood of the occupation tactic being used. Paradoxically, although fears of job loss contributed towards falling strike levels, many of the most high-profile occupations in Britain were organized in opposition to proposed redundancies and closures.

\footnotetext{
${ }^{56}$ Gregor Gall, 'Contemporary workplace occupations in Britain: Motivations, stimuli, dynamics and outcomes', Employee Relations, 33,6, 607-623, 613-4.

${ }^{57}$ Mills, 'Worker occupations, 1971-1975', 383.

${ }^{58}$ John Mcllroy, Strike! How to fight, how to win (Pluto: 1984), 134/5.

${ }^{59}$ David Grant, 'New Style agreements at Japanese transplants in the UK: The implications for trade union decline', Employee Relations, 16, 2 (1994), 65-83.

${ }^{60}$ Philip Basset, Strike Free: New Industrial Relations in Britain (London, PaperMac: 1987), 151.

${ }^{61}$ Wolfgang Streeck, 'The crises of democratic capitalism', New Left Review, 71 (2011), 5-29, 11.
} 
While overall numbers of occupations declined, as did strike levels more generally, the reasons for such decline differ in some significant respects. Unemployment, falling levels of manufacturing employment and plant closures suppressed strikes in general ${ }^{62}$ but in both the Gardner and Cammell Laird cases such fears had a galvanizing effect. The lack of alternative work in both Greater Manchester and Merseyside in the period undoubtedly motivated the strikers and formed a core part of their narratives as to why such strikes and occupations were justified and necessary. Debates prior to the decision to occupy at Lawrence Scott in 1981 referenced high local unemployment as a reason to not accept redundancy and attempt to resist closure plans, ${ }^{63}$ and the protests and publicity around the Lee Jeans occupation in Greenock were also framed in terms of regional deindustrialisation and lack of state support. ${ }^{64}$ The wider decline of strikes was in large part driven by fears of unemployment, and a fall in levels of strikes and attendant worker militancy inevitably reduced by extension the prevalence of occupations, but given that closures and job loss had, since the early 1970s and the wave of occupations following UCS, commonly been the catalyst behind the decision of striking workers to occupy, such reasons are inadequate in themselves to explain specifically why occupations declined in the period.

\section{The decline in incidence and duration of strike action in the 1980s}

Strike activity fell markedly in the 1980 s by measures of overall annual numbers of disputes (1,330 in 1980 to 620 in 1990), days not worked (11.96 million in 1980 to 1.9 million in 1990) and numbers of workers participating (834,000 in 1980 to 298,000 in 1990). ${ }^{65}$ The wider fall in manufacturing employment due to plant closures and downsizing, the increasingly precarious position of the remaining manufacturing workforce, weak economic recovery and increased international competition meant that these falls were particularly marked in this industrial sector ${ }^{66}$. The purpose of occupations was often to prevent products from leaving a factory as leverage within a wider dispute, but with a shrinking number of workplaces producing physical goods there was inevitably less scope for the use of such a tactic. The wave of occupations in the 1970s took place during a period of rising levels of strike activity and increasingly confident, militant worker mobilisations ${ }^{67}$. This provided a basis for workers to feel that job losses and closures were not inevitable and could be resisted, with occupations becoming part of a repertoire of tactics that was then extended into what the TUC had described as 'collective bargaining sit-ins', as with the Greater Manchester engineering occupations over pay in $1972^{68}$. While some extraordinarily long strikes took place in the 1980 s, such as the year-long miners' strike, the 22 month strike at Silentnight bed factories in 1985-7 ${ }^{69}$ and the 1986-7 News International dispute ${ }^{70}$, the general trend in the 1980 s and beyond was towards

\footnotetext{
${ }^{62}$ Michael Shalev, 'Strikes and the crisis: Industrial conflict and unemployment in the Western nations', Economic and Industrial Democracy, 4,4 (1983), 417-460.

${ }^{63}$ Love, Conflicts over Closure, 31.

${ }^{64}$ Lorentzen, 'The Lee Jeans Sit-in', 56.

${ }^{65}$ Dave Lyddon, 'From Strike Wave to Strike Drought: The United Kingdom, 1968-2005', in Sjaak van der Velden, Heiner Dribbusch, Dave Lyddon and Kurt Vandaele (eds), Strikes around the World, 1968-2005: Case-Studies of 15 Countries (Aksant, Amsterdam: 2007), 339-365, 365.

${ }^{66}$ James Piazza, 'Globalizing quiescence: globalization, union density and strikes in 15 industrialized countries', Economic and Industrial Democracy, 26,2 (2005), 289-314, 299-300.

${ }^{67}$ Lyddon, 'From Strike Wave to Strike Drought', 365.

${ }^{68}$ Gold, 'Worker Mobilization', 75.

${ }^{69}$ Stephen Mustchin, 'Dismissal of strikers and industrial disputes: the 1985-7 strike and mass sackings at Silentnight', Labor History, 55,4 (2014), 448-464.

${ }^{70}$ Peter Bain, 'The 1986-7 News International Dispute: Was the Workers' Defeat Inevitable?', Historical Studies in Industrial Relations, 5 (1998), 73-105.
} 
shorter strikes. ${ }^{71}$ The Gardner and Cammell Laird cases, at 7 weeks and 3 months respectively, were relatively long strikes where occupation was used as a tactic but with declining strike levels more generally the confidence needed among workers in order to effectively organize an occupation was seriously undermined. Employers had greater powers to dismiss striking workers under 1980s trade union legislation ${ }^{72}$, and the Cammell Laird case demonstrates that employers were increasingly willing to make use of state resources in terms of the law and law enforcement in order to prevent and break up strikes. Workers in both the Gardner and Cammell Laird occupations were highly aware of how their disputes were unusual in the period and should serve as an example to others who were subject to attrition from their employers. This was often framed in terms of opposition to the Thatcher government along with calls for other workers to take similar courses of action as a means of fighting back. However, examples of major defeats, the wider economic context, unemployment, hardening management attitudes including an increasing willingness to assert management prerogative through reprisals against strikers, the increased costs and risks of striking, and trends towards shorter, more symbolic strike action led to falling levels of industrial action in terms of incidence and duration. The use of occupations tended to occur within longer, more drawn out disputes, and the wider trend in terms of strike patterns militated against the use of the tactic.

\section{Anti-trade union legislation, strike regulation and the narrowing of immunities}

In successive statutes, (most notably the 1980 and 1982 Employment Acts and the 1984 Trade Union Act) the Thatcher governments passed legislation abolishing closed shop agreements, formalizing balloting procedures with regard to industrial action, outlawing secondary action, narrowing the legal immunities of striking workers and regulating the internal operations of unions and the election of officials. ${ }^{73}$ The direct impact of this legislation is contested as a core explanation for why strikes declined in the 1980s, and employers remained reluctant to use the legal instruments available to them. ${ }^{74}$ The decline of strikes was a feature of many other industrialized countries that did not pass such restrictive legislation and the argument is often made that wider calculations about the potential benefits and losses accruing from strikes, along with fears of employer reprisals (which were in part facilitated by the legislation but also by the wider political climate) and the 'disciplining' effect of international competition deriving from processes of globalization on workers were more significant factors ${ }^{75}$.

The abolition of the closed shop presented an obvious difficulty in terms of occupations - the Gardner case, arguably relatively successful in achieving the immediate aims of the workers in question, involved a closed shop and while some workers, most notably in white collar positions, did not join the action, the unity evident in the dispute in part derived from this arrangement. Balloting requirements, especially following the 1984 Trade Union Act, meant the speed of action necessary when organizing an occupation in order to lock out management and take control of the premises was lost, constituting an immediate legal barrier. The 1982 Employment Act narrowed immunities for striking workers - the 1974 Trade Unions and Labour Relations Act was somewhat ambiguous with regard to immunities. Legal opinion with regard to the 1982 Plessey dispute created a degree of uncertainty in terms of immunity from trespass law when breached in furtherance of a trade dispute. The 1982 Employment Act

\footnotetext{
${ }^{71}$ Dave Lyddon 'Rediscovering the past: recent British strike tactics in historical perspective.' Historical Studies in Industrial Relations, 5 (1998), 107-151.

${ }^{72}$ D.J. Denham, 'Unfair Dismissal Law and the Legitimation of Managerial Control', Capital and Class, 14 (1991), $83-101$.

${ }^{73}$ Paul Davies and Mark Freedland, Labour legislation and public policy: a contemporary history (Oxford, Clarendon Press: 1993)

${ }^{74}$ John Macinnes Thatcherism at Work. (Milton Keynes: Open University Press: 1987), 102.

${ }^{75}$ John Godard, 'What has happened to strikes?' British Journal of Industrial Relations, 49,2 (2011), 282-305; Lyddon, ‘From Strike Wave to Strike Drought', 365.
} 
explicitly abolished the clauses in the 1974 act that created these ambiguities. ${ }^{76}$ This, in conjunction with managers becoming increasingly emboldened in their dealings with strikers and with fewer concerns regarding the impact on harmonious industrial relations compared to the climate of the $1970 \mathrm{~s},{ }^{77}$ meant that eviction proceedings as a response to occupation became more feasible, as seen in the Cammell Laird case and also Laurence Scott in 1982. More interventionist policing was also a feature, as seen most famously in the 1984/5 miners' strike but also at Laurence Scott, the Stockport Messenger and News International disputes and others, involving heavy police presence at mass pickets and police escorts for non-striking workers. ${ }^{78}$ A three-day occupation at the Betteshanger colliery in Kent in 1984, involving eight workers involved in an underground sit-in, was broken up with workers dismissed on the basis of trespass. ${ }^{79}$ In the 1980s, employers encouraged by government were more forceful in their responses, framed within wider discourses of regaining managerial prerogative and notions of property rights, and legal injunctions, recourse to the police and similar became more prevalent within industrial disputes ${ }^{80}$. Scargill and the NUM were found guilty of contempt of court in $1984^{81}$, as was the TGWU over an unballoted strike at Austin Rover in $1984 .^{82}$ The use of legal injunctions, often concerned with picketing and secondary action, increased in the early 1980s, leading to a heightened threat of fines, sequestration of funds and contempt of court proceedings as well as increased caution on the part of union officials who were increasingly held responsible for the actions of their members. ${ }^{83}$ As the 1980s progressed such developments increasingly created barriers and deterrents to strikes in general and specifically the use of occupation as a strike tactic.

\section{Occupations and the demonstration effect}

The increasing prevalence of occupations in the 1970s followed the highly publicized, innovative and to an extent successful work-in at UCS in 1971. The wave of occupations that followed was to an extent inspired by $\mathrm{UCS}^{84}$, and this impact is often described as a (positive) demonstration effect where workers 'stand in a better position to deploy the [occupation] tactic because they are aware of a living example. ${ }^{, 85}$ Occupation was increasingly seen as a feasible tactic that in certain circumstances, especially in manufacturing where taking control of the premises and restricting goods from leaving the factory could strengthen the bargaining power of the workers involved, could deliver tangible gains, including in cases of threatened closure, redundancies and restructuring, but also as a means of enforcing more conventional bargaining demands such as pay. ${ }^{86}$ This took place within a wider context of growing worker militancy and confidence in the 1970 s - as strikes increased more generally, the minority that developed into occupations also increased in number. The more general decline of strikes in the 1980s was similarly marked by a fall in the use of occupations. While the 1980 Gardner dispute could be assessed as a comparative success, its leaders proclaiming it an 'inspiration to all workers

\footnotetext{
${ }^{76}$ P. Findlay, 'Resistance, Restructuring and Gender', 84.

77 'In Brief', Industrial Management, 76, 7 (1976), 5-8.

${ }^{78}$ Roger Geary, Policing industrial disputes: 1893 to 1985 (Cambridge University Press: 1985)

${ }^{79}$ Guardian, 19 June 1984

${ }^{80}$ Stephen Evans, 'The Use of Injunctions in Industrial Disputes May 1984-April 1987', British Journal of Industrial Relations, 25, 3(1987), 419-435.

${ }^{81}$ Guardian, 11 October 1984.

82 John Hutton, 'Industrial Action', Industrial Law Journal 14,4 (1985), 255-62.

${ }^{83}$ Stephen Evans, 'The Use of Injunctions in Industrial Disputes', British Journal of Industrial Relations 23,1 (1985), 13337.

${ }^{84}$ Foster and Woolfson, The Politics of the UCS Work-in, 394/5.

${ }^{85}$ Gall, 'Resisting recession and redundancy', 118

${ }^{86}$ Foster and Woolfson, The Politics of the UCS Work-in, 397.
} 
who detest this Government's policies ${ }^{97}$ that had prevented compulsory redundancies and delayed the process of downsizing that followed, and while some subsequent occupations could be deemed partially successful as with Lee Jeans in 1981 and Plessey in 1982, the onslaught of job losses and closures that took place in the early 1980s inevitably impacted on the confidence and cohesive workplace organization necessary to mount such campaigns. The response to the Laurence Scott occupation in 1981, and the major strike defeats that followed including Stockport Messenger, the miners and at News International played a wider role in dampening the propensity to strike. The dismissal of occupiers at Betteshanger in 1984 and the forceful response to the occupation at Cammell Laird would undoubtedly have impacted on those considering occupying their workplace given the risks of prison and increasing use of legal injunctions. Scepticism and caution with regards to occupation as a tactic was evident earlier, as in Batstone's study of workplace organisation and the dynamics of strikes ${ }^{88}$, but the mounting quantity of examples of strike defeats and the challenges of utilising the occupation tactic contributed towards a negative 'demonstration effect', in contrast to the upsurge of militancy following the example of UCS in the early 1970s.

\section{The decline of alternative forms of ownership: privatisation, cooperatives and workers control}

The partially successful outcome of UCS was premised on the government eventually backing down from their position of not intervening to support struggling businesses. Government support amounting to $£ 35$ million ( $£ 454$ million in 2018 values) was provided to rescue UCS, a 'massive u-turn in government policy' which became a key target for criticism from the Tory right in terms of the Heath government's weaknesses in pursuing a more pro-market neoliberal agenda. ${ }^{89}$ While some scope for state intervention existed within manufacturing in the 1970s, the emphasis on privatisation and not 'interfering' with the market by subsidising struggling companies that followed after the election of Thatcher removed one of the most significant possible outcomes for occupying workers, that the state would step in and prevent closures or job losses, narrowing the scope of what occupations could ultimately achieve. The 1984 Cammell Laird occupation was contextualised by such changes - shipbuilding had been nationalised in 1977 with its privatisation a Conservative manifesto commitment in 1979 and enacted in $1983 .{ }^{90}$ The Cammell Laird yard produced both military and civilian vessels with both state and private sector customers, but the occupation was a reaction to a context of falling demand and orders leading to job losses, in conjunction with a government that was more prepared to tolerate closures and less willing to support struggling producers under the auspices of allowing the market to function. The reluctance of the state to intervene to protect struggling firms and the obvious deterrent to attracting new private investment that an occupation would constitute contributed to the decline of its use as a tactic. Questions of ownership came to the fore during occupations and the debates that ran concurrently regarding the future of particular workplaces. These ranged from the highly unusual, as with the former Beatles associate the Maharishi Magesh Yogi claiming he could rescue the struggling Meccano toy factory in Liverpool if the workers embraced meditation and state aid was provided, ${ }^{91}$ to more conventional debates over state ownership and privatisation, and the wider movement of workers cooperatives inspired by debates over workers' control in the $1970 \mathrm{~s}^{92}$ Broader

\footnotetext{
${ }^{87}$ Mustchin, 'Conflict, mobilization and deindustrialization', 142.

${ }^{88}$ Batstone et al, The Social Organisation of Strikes, 178.

${ }^{89}$ Foster and Woolfson, The Politics of the UCS Work-in, 327.

${ }^{90}$ Alan McKinlay and Philip Taylor, 'Privatisation and Industrial Relations in British Shipbuilding', Industrial Relations Journal, 25,4 (1994),294.

${ }^{91}$ Brown, ‘Unions and Management in Engineering'; Independent, 18 December 1994.

${ }^{92}$ Ken Coates (Ed.). The New Worker Co-operatives. (Spokesman Books/ Institute for Workers Control: 1976); Gold, 'Worker Mobilization', 89.
} 
suggestions for worker-led restructuring of industry were features of the period, as with the Lucas plan on socially useful production and the Bullock report. ${ }^{93}$ The subsequent wave of closures, job losses and rising unemployment, along with the presence of a government and business lobby that explicitly rejected such proposals in comparison to the pre-1979 Labour governments, meant such approaches were increasingly difficult to contemplate let alone put into practice.

\section{The weakening of the far left and its impact on the organisation of occupations}

In most cases of occupations, key figures among the workplace leadership and within associated networks that supported and sustained lengthy strikes were active on the far left. Jimmy Reid, Sammy Barr and Jimmy Airlie, central figures in the UCS work-in, were CP members, and while there was little direct influence or direction from the parties in question the presence of a motivated, politicised network of workplace union leaders with the capacity to organise solidarity action was a major factor in developing leverage beyond the specific workplace under occupation. ${ }^{94}$ Three-quarters of occupations between 1971 and 1975 took place within ten miles of Glasgow, Manchester, Sheffield, Liverpool or London, all areas with relatively high levels of engineering employment at the time as well as comparatively influential CP networks. ${ }^{95}$ It has been argued that this was significant in cases where strikes evolved into occupations as such political affiliations involved being 'committed to challenging capitalism, and being prepared to consider more radical outcomes as end results of industrial actions. ${ }^{96}$ The CP was relatively powerful within the AUEW, the key union in a majority of workplace occupations in the 1970s and later, and it has been argued that the left leadership of the AUEW in the early 1970s gave it a responsiveness and level of support to workplace level organisation that was important in terms of gaining official support for such actions. ${ }^{97}$ Such support was lacking in later years and the Gardner workers felt forced to threaten the union leadership with a sit-in at their headquarters if strike pay was not forthcoming. ${ }^{98} \mathrm{CP}$ presence among workplace union leaderships was significant in the 1972 Greater Manchester engineering occupations, and stewards from Fisher Bendix and Gardner were involved with the 'rank and file' CP network the Liaison Committee for the Defence of Trade Unions in the early 1970s. ${ }^{99}$

In the 1980 Gardner occupation, the leaders of the dispute included the convenor, Tommy Macafee, a CP member, and Mick Brightman who was active in the SWP. This proved invaluable in terms of raising the profile of the dispute, which was covered closely in the left press, particularly in Socialist Worker and the Morning Star. In the period preceding the final negotiations, conducted by Manchester AUEW official John Tocher, formerly a CP member himself, which ultimately settled the dispute, commitments to 'black' Gardner products at key English ports and which were facilitated by the links made between the leadership of the Gardner workers and dockworkers' unions through left networks, were thought to have been key in ultimately pressuring Gardner management and the parent company Hawker Siddeley into settling and withdrawing the originally proposed compulsory redundancies. ${ }^{100}$ At Laurence Scott in 1981, the occupying workers again had support from activists linked to the

\footnotetext{
${ }^{93}$ Phillips, 'UK Business Power'; Hilary Wainwright and Dave Elliott, The Lucas Plan: a new trade unionism in the making? (Allison and Busby: 1982)

${ }_{94}^{94}$ Foster and Woolfson, The Politics of the UCS Work-in, 398/9.

${ }^{95}$ Ibid., 395.

${ }^{96}$ Mills, 'Worker occupations', 410.

${ }^{97}$ Ibid.,.403.

${ }^{98}$ Mustchin, 'Conflict, mobilization and deindustrialization', 156.

99 John Mcllroy and Alan Campbell 'Organizing the Militants: The Liaison Committee for the Defence of Trade Unions, 19661979', British Journal of Industrial Relations, 37,1: (1999), 1-31.

${ }^{100}$ Mustchin, 'Conflict, Mobilization and Deindustrialisation'
} 
CP and SWP but, significantly, CP support was limited following calls by the strike committee to remove the AUEW executive council who, it was felt, had betrayed them, a move which the CP leadership believed would have limited support among the 'rank and file.' ${ }^{101}$ In the 1984 Cammell Laird occupation, political affiliations played little direct role in directing the dispute but support from far left groupings was significant, with Barry Williams, a CP member and official within the GMBATU union, a key figure in maintaining the pickets and ongoing protests in support of the occupiers ${ }^{102}$. Support from the then Militant-led Labour council was also evident, with attempts made to offer them the honour of freedom of the city as well as permitting one day walkouts among local authority workers in solidarity with the workers at Cammell Laird. Support from AUEW networks, a labour movement with the historical memory of UCS, and familial networks were important in developing the solidarity networks associated with the 1987 Caterpillar occupation ${ }^{103}$. With major falls in AUEW membership in the 1980s, the decline of the CP's industrial membership and the subsequent weakening of the networks they engaged with ${ }^{104}$, occupations became more difficult to sustain both in terms of delegation work to raise funds and collect statements of support and solidarity, as well as in more practical terms such as organising 'blacking' of goods. Changes in the law to outlaw secondary picketing also weakened the influence of such networks. The more general weakening of the AUEW, its increasingly right-wing leadership and the distancing of the farleft from the union movement in this period ${ }^{105}$ had an impact as they played a key role in framing disputes, drawing on historical experience in order to inform strike tactics, and raising awareness of successful disputes and occupations elsewhere.

\section{The decline of workplace occupations in the 1980s and the enduring role of the occupation tactic}

The explanatory factors outline above all contributed towards the decline of occupations, but none are sufficient in themselves to explain such decline and there is a need to explore the dynamic relationship between them. As outlined above with reference to Gall, six influences explaining why workers might undertake occupations include collectivised redundancies, the immediate and unforeseen nature of redundancy; loss of pensions; pre-existing collective organisation; and positive demonstration effects or prominent examples of occupations deemed to be successful. ${ }^{106}$ The analysis above builds on this explanatory framework to explore why the use of the occupation tactic declined, including the contraction of manufacturing and rising unemployment; overall falls in strike incidence and strike duration; anti-union legislation and policing; negative demonstration effects; narrowed scope for alternative forms of ownership including nationalization and workers cooperatives, and the weakening of the far-left. Such factors are interrelated. Strikes had historically been most prevalent in manufacturing, mining, the docks and similar industries that entered a secular decline in the 1980s - the sheer reduction in numbers of workers employed in such industries and widespread closures in the 1980s markedly reduced the size of the cohort of workers in industries where strikes and occupations were most likely. Fear of unemployment and international competition were disciplining factors underpinning the overall reduction in incidence and duration of strikes. Anti-union

\footnotetext{
${ }^{101}$ Love, Conflict over Closure, 99.

102 Brian Marren We Shall Not Be Moved: How Liverpool's Working Class fought redundancies, closures and cuts in the age of Thatcher. (Manchester University Press: 2016), 190.

${ }^{103}$ Woolfson and Foster, Track Record; Gibbs and Phillips 'Who owns a factory?'

104 John Mcllroy, 'Notes on the Communist Party and Industrial Politics,' in Mcllroy et al, The High Tide of British Trade Unionism, 216-258,. 246-7.

${ }^{105}$ Ralf Hoffrogge, 'Engineering New Labour: Trade unions, social partnership, and the stabilization of British neoliberalism, 1985-2002', Journal of Labor and Society, 21, 3 (2018), 301-316.

106 Gall, 'Contemporary workplace occupations in Britain'
} 
legislation, employer willingness to confront striking workers with legal interventions, the intensified focus of the police on picketing, and the prospect of eviction and sanctions on unions and individual workers were also significant factors, relating to a changed role for the state that was also reflected in its strategy of non-intervention in terms of support for struggling industries and firms. The decreased influence of the far-left is also significant - debates on alternative forms of ownership had been driven by the increasingly influential left of the Labour Party and wider networks in the 1970s, and more generally in the 1980s the left suffered reduced influence within unions and particularly within workplace union organisation

The six factors outlined here are evidently interlinked, but overall the main reasons for the decline of occupations correspond with explanations as to why strikes declined more generally. The six influences identified by Gall to explain why occupations took place are useful in explaining why they declined. However, collectivised redundancies increased markedly during the 1980s, were often sudden and unpredictable with pensions frequently lost, collective organisation remained comparatively strong through much of the 1980s despite the challenges faced, and some at least partially successful examples existed, such as Gardner and others. While such stimuli are certainly important in understanding occupations in the rare situations when they took place, they were present within the period in which occupations were in decline, highlighting the wider economic, political and legal challenges faced by those contemplating occupation in the 1980s.

The focus of this paper, both in explaining why occupations declined in the 1980s and how they typically focused on job losses, redundancy terms and other staples of collective bargaining as opposed to more radical agendas in no way negates the significance of work-ins. The UCS case, worker-controlled cooperatives in the Britain in the $1970 \mathrm{~s}^{107}$; the occupied then worker-managed Lip watch company in 1970s France, the self-managed factory movement in Argentina in the 2000s, occupations and work-ins in Spain and Greece in the face of austerity after $2010^{108}$, and similar were significant self-organised actions and such 'collective administration' has been identified as a 'natural tendency of rank-and-file workers', even those without knowledge 'of previous [worker] council experiences' in other countries or periods. ${ }^{109}$ Occupations in export processing zones in Indonesia in 2009 and $2012^{110}$, Russia after $2008^{111}$ and China in the late 1990s and more recently ${ }^{112}$ demonstrate the enduring use of the tactic, especially in more recently developing regions of the wider global economy, even though the tactic has become very rare in more 'mature' industrialised countries. This resonates with the notion that as capital expands, conflict is shifted to the periphery of its operations, as well as highlighting the way that forms of struggle transform during periods of economic restructuring, including both growth and contraction. ${ }^{113}$ In studying conflict at work, Thompson identifies strategies of resistance as opposed to strategies of transformation ${ }^{114}$ - the latter would apply to approaches involving occupation leading to workers control and similar, but given the challenges faced by unions since the 1980s, it is perhaps unsurprising that occupation in Britain

\footnotetext{
${ }^{107}$ Gold, 'Worker Mobilization in the 1970s'

${ }^{108}$ Maurizio Atzeni and Pablo Ghigliani, 'Labour process and decision-making in factories under workers' self-management: empirical evidence from Argentina', Work, Employment and Society, 21,4, (2007), 653-671. Anna Koumandaraki and Athanasios Tsakiris 'Gender and Precarity in Crisis-Ridden Greece.' In Jorg Nowak, Madhumita Dutta and Peter Birke (eds.) Workers' Movements and Strikes in the Twenty-First Century: A Global Perspective (Rowman and Littlefield; 2018), 273-88; Martinez Lucio, 'From action to communication?'; Donald Reid, Opening the Gates: the Lip Affair 1968-1981. (Verso: 2018) ${ }^{109}$ Ness and Azzelini, 'Introduction', in Ness and Azzelini, Ours to Master and to Own, 1-7, 1

${ }^{110}$ Fahmi Panimbang and Abu Mufakir, 'Labour Strikes in Post-Authoritarian Indonesia, 1998-2013', in Nowak et al, Workers' Movements and Strikes, 21-44.

${ }^{111}$ Elena Gerasimova and Petr Bizyukov, 'The Strike Movement and Labour Protests in Russia', in Nowak et al, Workers' Movements and Strikes, 289-306.

${ }^{112}$ Shih-Diing Liu and Wei Shi 'Worker struggles and factory occupation in China during the current economic crisis', Social Movement Studies, 16,3 (2017), 355-360.

${ }^{113}$ Silver, Forces of Labor

${ }^{114}$ Paul Thompson, The nature of work: An introduction to debates on the labour process (Macmillan: 1983), 236.
} 
has more commonly conformed to the former approach of defending jobs, resisting redundancies and advancing more conventional bargaining demands.

Occupations have endured to some extent as seen with the examples cited above after 2008, but are rare, typically of a relatively short duration and often used for more symbolic purposes, as with the IWGB sit-ins in corporate headquarters, rather than seeking to physically prevent goods or products from leaving a workplace. While occupations instigated by left-wing activists linked to the labour movement have declined drastically, other social movements and protest groups have continued to use occupation as a tactic. Occupations more generally have become prominent within social movements beyond labour - as with, inter alia, the Occupy movement ${ }^{115}$, the 'occupations' of public squares in Egypt and Greece in 2011 and afterwards ${ }^{116}$, and among student activists in the UK since 2010 in opposition to fees and marketization in higher education. ${ }^{117}$ This literature on occupations as used by non-labour social movements makes little reference to the use of occupations in economic struggles and strikes, and it has been argued that such occupations' problems in seizing assets, developing leverage and bargaining power, and moving beyond a more generalised critique to more specific, achievable demands have often limited their impact ${ }^{118}$, despite the innovative protest tactics they deployed. ${ }^{119}$ This serves as an example of how some social movements and some of those who study them have become separated from workers movements and the concerns of organised labour. The relationship between labour and social movements has often been problematic, but has arguably been exacerbated by the general weakening of the labour movement and a wider sociological 'turn' that minimizes the role of workers within the wider phenomenon of social protest.

\footnotetext{
115 J.S. Juris, 'Reflections on \#Occupy Everywhere: Social media, public space, and emerging logics of aggregation', American Ethnologist, 39,2 (2012), 259-279.

${ }^{116}$ Marilena Simiti, 'Rage and protest: the case of the Greek Indignant Movement', Contention: The Multidisciplinary Journal of Social Protest 3,2 (2016), 33-50.

117 Alexander Hensby, 'Networks of non-participation: Comparing 'supportive', 'unsupportive' and 'undecided' nonparticipants in the UK student protests against fees and cuts', Sociology, 51, 5 (2017), 957-974.; Yannis Theocharis, 'Cuts, Tweets, Solidarity and Mobilisation: How the Internet Shaped the Student Occupations', Parliamentary Affairs 65, (2012), $162-194$.

118 Gall, 'Occupations, not Occupy!'

${ }^{119}$ Joseph Ibrahim, 'The New Toll on Higher Education and the UK Student Revolts of 2010-2011,' Social Movement Studies, 10, 4 (2011), 415-421.
} 